\title{
Preparation of Large Molecular Weight DNA from the Fungus Aspergillus nidulans
}

\author{
By N. RONALD MORRIS \\ Department of Pharmacology, CMDNJ-Rutgers Medical School, P.O. Box 101, \\ Piscataway, New Jersey 08854, U.S.A.
}

(Received 1 December 1977)

\begin{abstract}
Development of the molecular biology of the filamentous fungi has been limited by the unavailability of a good general method for preparation of large molecular weight DNA for restriction analysis. Large molecular weight DNA has been prepared from isolated nuclei of Aspergillus nidulans (Morris, 1976) and Neurospora crassa (Hautala et al., 1977), but to my knowledge total cellular DNA of large molecular weight has not been prepared in large amounts either from the spores or from the vegetative mycelium of any filamentous fungus. There have been two major technical problems. The first is that fungi contain very small amounts of DNA and have very active DNAases. The second is that both the spores and the vegetative mycelia of filamentous fungi have extremely tough walls and there have been no good, gentle methods for opening either spores or mycelia without causing shearing of DNA. Both of these problems have recently been solved. Spores can be opened by vortexing with glass beads (Van Etten \& Freer, 1978) and mycelia can be made into protoplasts (de Vries, 1974) which are then easily lysed with detergent. I have discovered, during the course of trying to develop a new method for isolation of nuclei from $A$. nidulans, that the intracellular DNAases of $A$. nidulans are inhibited by EDTA. The purpose of this short communication is to describe a method for the preparation of large molecular weight DNA from spores and from protoplasts prepared from vegetative mycelium of $A$. nidulans.
\end{abstract}

DNA can be prepared from conidial spores by the following procedure. Conidia $(2 \mathrm{~g})$ are harvested into a $30 \mathrm{ml}$ siliconized glass centrifuge tube and washed twice with $20 \mathrm{ml}$ of cold lysis buffer ( $5 \mathrm{~mm}$-spermidine, $100 \mathrm{~mm}-\mathrm{KCl}, 10 \mathrm{~mm}-\mathrm{Na}_{2} \mathrm{EDTA}, 10 \mathrm{mM}$-Tris/ $\mathrm{HCl} \mathrm{pH}$ $7 \cdot 4,0.25 \mathrm{M}$-sucrose). The conidia are ruptured and nuclei are released by vortexing with glass beads (Van Etten \& Freer, 1978): $10 \mathrm{~g}$ acid washed 0.17 mm Braunwell (Braunwell Industries) glass beads and $2.5 \mathrm{ml}$ of cold lysis buffer are added to the conidial pellet, mixed well with a glass rod and the suspension is vortexed on a Vortex-Genie Mixer at a setting of 10 until $90 \%$ of the spores are broken, as determined by inspection under the phase microscope. This requires 60 to $90 \mathrm{~s}$ of vortexing (smaller quantities of conidia can be broken in shorter times). The ruptured spores are harvested by stirring with two additions of 3 to $4 \mathrm{ml}$ of cold lysis buffer followed by sedimentation of the glass beads by gravity for a few minutes. The spores are harvested with the supernatant liquid. The purpose of the spermine buffer system is to maintain a compact nuclear morphology until lysis in detergent so as to minimize DNA shearing during the vortexing procedure. Sodium dodecyl sulphate (SDS) is added to the suspension of ruptured spores to a final concentration of $1 \%(\mathrm{w} / \mathrm{v})$. The lysate is heated to $60^{\circ} \mathrm{C}$ for $20 \mathrm{~min}$ and then incubated with proteinase $\mathrm{K}\left(200 \mu \mathrm{g} \mathrm{ml}^{-1}\right.$, Boehringer) for $16 \mathrm{~h}$ (overnight) at $42{ }^{\circ} \mathrm{C}$. The lysate is then deproteinized by gentle mixing with an equal volume of freshly distilled phenol equilibrated with $0.5 \mathrm{M}$-Tris/ $\mathrm{HCl} \mathrm{pH} \mathrm{8.0.}$ After centrifugation, the aqueous phase is removed and deproteinized again with phenol. The phenol is then removed by dialysis against $0.05 \mathrm{M}-\mathrm{Tris} / \mathrm{HCl} \mathrm{pH} 8.0,10 \mathrm{~mm}-\mathrm{Na}_{2}$ EDTA, $100 \mathrm{~mm}-\mathrm{KCl}$. RNAase A (preheated to $80^{\circ} \mathrm{C}$ for $30 \mathrm{~min}$ ) is added to a final concentration 


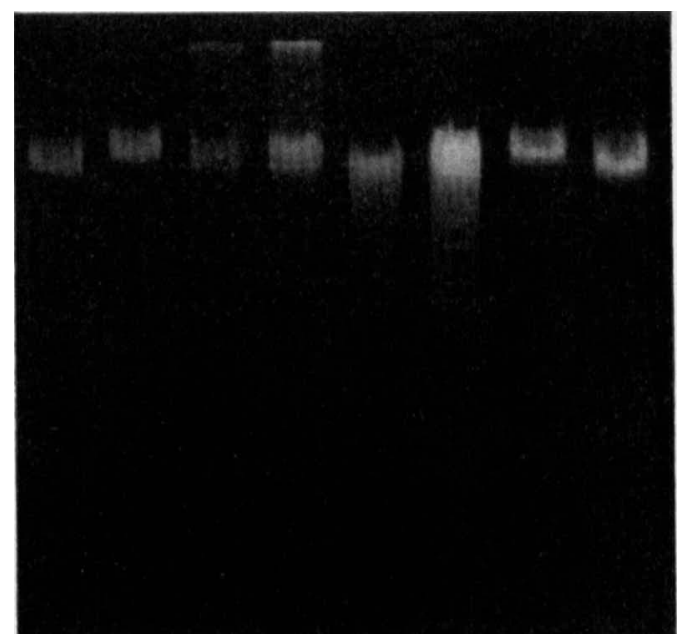

Fig. 1. Comparison of the electrophoretic mobilities of $A$. nidulans spore and protoplast DNA with known molecular weight markers. From left to right: T7 DNA $\left(2 \cdot 6 \times 10^{7}\right.$ daltons); $\lambda$ DNA ( $3.2 \times 10^{7}$ daltons); $1 \mu \mathrm{g}$ protoplast DNA; $2 \mu \mathrm{g}$ protoplast DNA; $1 \mu \mathrm{g}$ spore DNA; $2 \mu \mathrm{g}$ spore DNA; $\lambda$ DNA; T7 DNA. Electrophoresis was for $4 \mathrm{~h}$ at $40 \mathrm{~V}$ in $0.5 \%(\mathrm{w} / \mathrm{v})$ agarose (Seakem) with 40 mM-Tris/acetic acid pH 7.4, 2 mm-EDTA.

of $200 \mu \mathrm{g} \mathrm{ml}^{-1}$ and the lysate is incubated for $1 \mathrm{~h}$ at $42{ }^{\circ} \mathrm{C}$. RNAase is removed by treatment with phenol and the phenol removed by dialysis. The volume of the DNA solution is then reduced by burying the dialysis bag in polyethylene glycol (Carbowax 4000 , Union Carbide) for 30 to $60 \mathrm{~min}$. This removes 50 to $75 \%$ of the volume. A final dialysis is used to put the DNA into any desired storage buffer. We routinely store Aspergillus DNA at $4{ }^{\circ} \mathrm{C}$ in $20 \mathrm{~mm}$-Tris/acetic acid pH 7.4, 2 mM-Na ${ }_{2}$ EDTA. Recovery of DNA is approximately $250 \mu \mathrm{g}$ DNA per $\mathrm{g}$ spores.

Large molecular weight DNA can also be made from protoplasts. Protoplasts are prepared by a modification of the method of de Vries (1974). Aspergillus nidulans is grown from an inoculum of $3 \times 10^{6}$ conidia $\mathrm{ml}^{-1}$ for 12 to $14 \mathrm{~h}$ at $30^{\circ} \mathrm{C}$ in Czapek-Dox broth (Difco), supplemented with growth factors as required, in a reciprocating incubator shaker (Controlled Environment Incubator Shaker, New Brunswick Scientific Co.) at $150 \mathrm{rev} . \mathrm{min}^{-1}$. Drained mycelium $(5 \mathrm{~g})$ is resuspended at $25 \mathrm{mg} \mathrm{ml}{ }^{-1}$ in $0.5 \mathrm{M}-\mathrm{MgSO}_{4}, 0.05 \mathrm{M}$-sodium maleate buffer $\mathrm{pH} 5 \cdot 8$, and to this suspension is added Trichoderma lytic enzyme (de Vries, 1974) at $4 \mathrm{mg} \mathrm{ml}^{-1}$ plus $1 \%$ of a snail gut lytic enzyme preparation (Glusylase, Endo Labs, extensively dialysed against the above buffer). The suspension is shaken gently at $30^{\circ} \mathrm{C}$ with a large surface/volume ratio (100 $\mathrm{ml}$ in a $500 \mathrm{ml} \mathrm{flask})$. Under these conditions protoplast formation appears to be nearly complete in 1 to $2 \mathrm{~h}$; however, incubation is continued for $10 \mathrm{~h}$ to allow the metabolically active protoplasts to develop large vacuoles. The protoplasts are then centrifuged at $10000 \mathrm{rev} . \mathrm{min}^{-1}(16300 \mathrm{~g})$ for $10 \mathrm{~min}$ in the Sorvall HB-4 swinging bucket rotor to float vacuolated protoplasts, and the vacuolated protoplasts are harvested by skimming the surface with a spatula or with a Pasteur pipette. Typically 0.5 to $0.75 \mathrm{~g}$ vacuolated protoplasts can be obtained from $5 \mathrm{~g}$ mycelium. The skimmed protoplasts are diluted with 2 vol. of cold $0.5 \mathrm{M}-\mathrm{KCl}$ and sedimented by centrifugation at 10000 rev. $\mathrm{min}^{-1}$ for $5 \mathrm{~min}$ in the HB-4 rotor. The protoplast pellet is washed twice with $30 \mathrm{ml}$ of cold $0.5 \mathrm{M}-\mathrm{KCl}$ to remove residual $\mathrm{MgSO}_{4}$. The protoplasts are suspended in 10 to $15 \mathrm{vol}$. of $50 \mathrm{mM}$-Tris/ $\mathrm{HCl} \mathrm{pH} 8 \cdot 0,50 \mathrm{mM}-\mathrm{Na}_{2}$ EDTA, SDS is immediately added to a final concentration of $1 \%(\mathrm{w} / \mathrm{v})$ and the lysis mixture is heated to $60^{\circ} \mathrm{C}$ for $20 \mathrm{~min}$. The remainder of the procedure is the same as for obtaining DNA from spores. The yield is about 
$450 \mu \mathrm{g}$ DNA per $\mathrm{g}$ protoplasts. The molecular weight of the bulk of the DNA obtained from both spores and protoplasts by this method is about $3 \times 10^{7}$ (Fig. 1).

This work was supported by grants CA 10665 and GM 23060 of the National Institutes of Health. I would like to thank Don Benson for excellent technical assistance.

\section{REFERENCES}

Hautala, J. A., Conner, B. H., Jacobson, J. W., Patel, G. L. \& Giles, N. H. (1977). Isolation and characterization of nuclei from Neurospora crassa. Journal of Bacteriology 130, 704-713.

MORRIS, N. R. (1976). Nucleosome structure in Aspergillus nidulans. Cell 8, 357-363.

VAN EtTen, J. \& Freer, S. N. (1978). A simple procedure for disruption of fungal spores. Journal of Applied and Environmental Microbiology (in the Press).

DE VRIES, O. M. H. (1974). Formation and cell wall regeneration of protoplasts from Schizophyllum commune. Thesis, University of Groningen, The Netherlands. 